\title{
HOW TO IMPACT FRANCHISEE ADJUSTMENT: AN EMPIRICAL EXAMINATION OF FRANCHISOR SUPPORT
}

\author{
Markus Blut, Newcastle University, United Kingdom \\ Christof Backhaus, Technische Universität Braunschweig, Germany \\ David M. Woisetschläger, Technische Universität Braunschweig, Germany \\ Heiner Evanschitzky, Aston University, United Kingdom \\ Tobias Heussler, DB Management Consulting, Germany
}

\begin{abstract}
The decision to enter a franchise system and to become a franchisee represents an important change in an individual's work environment (Kaufmann and Stanworth 1995). Once having signed a franchise contract, franchisees usually give up their current jobs and have to learn how to successfully establish and operate a franchise business. The initial phase of an individual's engagement as a franchisee is often accompanied by entrepreneurial euphoria, resulting from the fascination and excitement of beginning a new phase in their working life (Frazer 2001). However, recent research on relationship formation between franchisees and franchisors indicates that after some time, this initial fascination decreases due to sobering experiences with the franchise system. Blut and colleagues (2011) argue that this typical downturn of relationship properties may lead to a number of negative consequences such as increased opportunism of the franchisees, reduced investments, and lowered operational input (Oxenfeldt and Kelly 1968). Thus, it is important for the franchisor to understand why some franchisees adjust well after some time while others do not. Against this background, the contribution of this study is twofold. First, it develops a conceptual model of factors influencing the adjustment of franchisees during their first years. Second, it empirically tests the model including measures in the area of (a) job design, (b) knowledge management, and (c) attractiveness of the franchise using a matched sample consisting of 32 franchise systems and 1,581 franchisees. Based mainly on arguments from the expatriate literature and from social learning theory, we empirically test three hypotheses:
\end{abstract}

H1: The decrease of franchisee satisfaction, trust, and commitment when franchisees move from the honeymoon to disillusionment stage is weaker in those franchise systems in which franchisees (a) are granted a high degree of autonomy (b) and in which franchisees are motivated to actively participate in decision making.

H2: The decrease of franchisee satisfaction, trust, and commitment when franchisees move from the honeymoon to disillusionment stage is weaker in those franchise systems in which (a) franchisors extensively transfer knowledge to their franchisees and in which (b) a high percentage of franchisees has experience through prior self-employment.

H3: The decrease of franchisee satisfaction, trust, and commitment when franchisees move from the honeymoon to disillusionment stage is weaker in those franchise systems characterized by (a) lower initial investments, (b) lower royalty rates, (c) greater contract lengths, and (d) better reputation of the franchise system.

Due to the nested nature of the data, we test our model using a multilevel regression model. Looking at the level-1 regression results, we note that franchisee satisfaction is significantly lower for franchisees in the disillusionment stage. We also find two significant negative effects on franchisee trust and franchisee commitment. These results indicate that after a period of excitement, franchisees experience disillusionment leading to lower relational properties. Turning to the level-2 effects, we find several cross-level interactions of measures in the area of job design, knowledge management, and attractiveness of the franchise. As expected through our conceptual reasoning, a high degree of franchisee autonomy, franchisee participation, knowledge transfer, prior self-employment, royalty, and reputation of the system buffer the disillusionment of franchisees for each of the three relationship properties, satisfaction, trust, and commitment. Moreover, initial investments are found to display only a buffering effect for trust but not for satisfaction and commitment. Finally, we do not find a cross-level interaction for contract length neither on the slopes of lifecycle-stage on satisfaction, trust, nor commitment. In sum, the results indicate that franchisors can indeed facilitate franchisee adjustment.

References Available Upon Request 